\title{
Ebooks in further education
}

\author{
David Scott \\ Dundee and Angus College
}

The adoption of ebooks in further education (FE) colleges across the UK has been driven forward in large measure by the Jisc funded ebooks for FE project ${ }^{1}$. This initiative, which was established in 2009 and ended in August 2014, has provided all colleges in the UK with free access to a collection of approximately 3000 ebooks from a range of well-known publishers. In attempting to paint a picture of the landscape of ebooks across this very varied sector we have surveyed the views of librarians in 25 colleges which make heavy use of this collection, as well as taking note of recently published reports. The survey covered issues such as: ebooks strategies; access to ebooks; integration of ebooks with other institutional systems such as virtual learning environments (VLE) and library management systems (LMS); barriers to usage - cultural, technical; and the ebooks landscape in the next three years. It was sent to a range of colleges which reported high use of the ebooks collection by their students and staff, as defined by the monthly statistics provided by Jisc Collections. A high proportion of the institutions surveyed were in the top twenty of student users of the Jisc ebooks collection. Inevitably with such

${ }^{1}$ http://fe.jiscebooks.org/

\section{How to cite this book chapter:}

Scott, D. 2014. Ebooks in further education. In: Woodward, H. (ed.) Ebooks in Education: Realising the Vision. Pp. 9-14. London: Ubiquity Press. DOI: http://dx.doi.org/10.5334/bal.b 
a survey, the recurrent top users were larger colleges, but they did represent views of colleges from across the UK.

\section{Survey of FE libraries}

FE is weighted heavily towards vocational education and training. The information needs of staff and students are therefore largely focused on up-todate relevant materials which support teaching and learning. Ebooks provide college libraries with the opportunity to increase access to high-demand textbooks and supplement their print collections. Their enhanced features and functionality help address a number of accessibility issues. We have not identified any strong strategic drivers in colleges on the development of their ebook collections; however, there is a desire expressed by all librarians who were surveyed to provide an alternative to multiple copies of textbooks. In the main this is driven by costs, but a number mentioned the influence of new library builds and refurbishments with reduced floor space available for book collections. One college ensures that it always purchases an ebook (if it exists) for any core text that is on a recommended booklist. Another college, which provides higher and further education qualifications in equal measure, builds its ebook collection by reference to course validation recommendations. In the past 18 months this college has also extended its provision for higher education students using resources available through the Scottish Higher Education Digital Library (SHEDL). Aside from the Jisc ebooks collection, the main additional sources of ebooks for colleges are the major aggregators such as Dawsonera, Coutts and MyiLibrary.

\section{Authentication}

Shibboleth is the main access and authentication system used in the libraries we surveyed, with Athens and IP addresses as less flexible alternatives. This appears to be a better position than four years ago, when it was reported that "over a third of colleges have yet to become Athens or UK Federated Access Management (Shibboleth) compliant” (Cox et al. 2010, p.8). Accessibility problems were still reported by $24 \%$ of survey respondents in an ebooks evaluation report as late as 2013 (Conyers and Dalton 2013, p.28) though it made clear that this referred to wider issues than just authentication. However, with an increase in mergers of colleges that are geographically distant from each other, changes in modes of delivery of the curriculum, and an increase in independent study methods, it has become even more important to be able to provide access to ebooks and other digital resources both on and off campus. 


\section{Embedding of ebooks}

Embedding the ebooks collection into the teaching and learning processes of colleges and their library services has developed well since it was reported in 2010 (Cox et al. 2010, p.27) that there was a lack of synergy between the staff involved in developing the ebooks collection and those involved in maintaining and populating the institutional virtual learning environment (VLE). All of the respondents in our recent survey reported that their ebooks were embedded into their VLE, with a number stating that this was implemented at the individual course level, providing students with direct access to relevant materials to complement their studies. At one college, academic liaison librarians worked closely with curriculum and learning technology teams to ensure that their ebooks were linked to all courses, and this strategic approach had had an impact on the use of the collection as well as building strong professional relationships. One college had specifically promoted their ebooks to online and distance learning students who had traditionally received a poorer, less comprehensive library service. All libraries surveyed had enabled their collection to be searchable on their library catalogue with most suggesting that this had increased both the awareness of and the use of ebooks as well as facilitating off-campus access to library materials.

\section{Barriers and problems}

Cultural barriers continue to impede progress in the adoption and use of ebooks. Negative staff and student attitudes were mentioned in a 2013 report (Conyers and Dalton 2013, p.27). However, our recent survey of librarians would suggest that this resistance is focused today amongst a smaller number of traditional lecturers who are less digitally competent and more comfortable with the printed book. Conversely, it was reported by the librarians that we surveyed that a number of teaching staff (as well as academic liaison librarians) are using ebooks as a teaching tool, either in class sessions with an electronic whiteboard or building their use into online learning activities or assessments. Buy-in from lecturers is seen as key to making students aware of and enthusiastic about the use of ebooks and there is strong anecdotal evidence that a joint approach between the library and teaching staff often results in a positive impact on their perception and overall usage. One college library reported that in working closely with their supported learning team (a staff resource which supports the additional needs of disabled students and those with a learning difficulty), they had developed a continuing professional development (CPD) programme which ensured that both teaching and academic support staff were made aware of and able to exploit the advantages of the enhanced functionality of ebooks. 
Technical issues are still a major source of frustration in accessing ebooks easily. This was reported in 2013 (Conyers and Dalton 2013, p.29), and in our survey most of the librarians complained about navigation issues for staff and students in using ebook platforms. There were strong views expressed about the need for standardisation across the range of suppliers' platforms. FE colleges subscribe to the Jisc ebooks collection as well as purchasing books from Dawsonera, Coutts and others. They all have different platforms which can be frustrating for the end user and can promote negative attitudes towards the use of ebooks to support their studies, particularly among those who are used to the ease of downloading and accessing books on to devices such as Kindles and iPads. The ease of use of these devices is often seen in contrast to the perceived difficulties of accessing ebooks. Equally, there were views expressed about the "clunky" look and feel of some of the platforms as well as the additional software and procedures related to digital rights management (DRM) often required to download ebooks.

Libraries are still facing difficulties in acquiring electronic versions of textbooks, particularly up-to-date versions. Textbooks are a vital element in the publishers' business model; they sell vast numbers directly to students as well as libraries. Jisc Collections are in a good position to work with publishers to ensure that more up-to-date and relevant books are available to the sector.

\section{Innovations}

Libraries have become increasingly adept at promoting their services to their users, and many employ a range of measures to ensure that ebooks are seen as an increasingly important part of the overall service. Apart from adding all the ebook titles to the library catalogue and also linking them in a variety of ways to specific courses developed by teaching staff on their institutional VLEs, they are also promoted in a number of creative and engaging ways. Colleges have developed a range of enhanced induction workshops, as well as working closely with curriculum staff on the development of study and research skill programmes which enable students to become aware of and adept at accessing and using ebooks. The advantages of ebooks are built into the teaching and learning process with lecturers demonstrating their use during lectures and classes, as well as devising activities and assessments which demonstrate their increased accessibility, flexibility and functionality. Some libraries have adopted the bookshop approach to signposting, using QR codes on shelves to provide further information and a direct link to the individual ebook. Complementary to this, some libraries are using DVD style boxes or cards to promote ebooks which they shelve or place adjacent to other relevant print-based textbooks. Posters, flyers and placing details of the ebook 
collection on the college website, student online portal and social media pages all play a part in their promotion.

Colleges have reported that their ebook collection has proved invaluable to their online and distance learning students. Not only has it enhanced the service to these learners but it has also enabled the library to reduce the administrative processes required to provide print-based texts by post. The benefits to this relatively small number of specific users could well be a key driver to support the information needs of many more full-time and part-time students at the increasing number of merged colleges across the country. A number of these merged colleges are geographically far apart, with practical difficulties for students in accessing resources at more than their local campus. For example, in 2012 there were 43 FE colleges in Scotland, but in April 2014 there were only 13, some of which have campuses more than 40 miles apart. Ebook collections will be even more important in ensuring that students have access to relevant resources when they need them.

\section{Future prospects}

All of the librarians we contacted thought that the demand for ebooks by students was likely to increase over the next three years. The increase in the number and range of smartphones has resulted in a consequent increased demand by students for mobile access to their timetables, course materials and as study support tools such as ebooks. It will become a focus for Jisc Collections and consortia such as the SHEDL and the Welsh Higher Education Libraries Forum (WHELF) to support the demand for up-to-date ebooks to ensure that student and staff demands are met. Further work is also required in trying to establish a set of standards in the processes involved in accessing, downloading and repurposing the content of ebooks. There are strong messages coming from the sector that the process for students is too cumbersome, with many confused and frustrated by the varying licence conditions.

Ebooks are now a significant element in the FE library service. I cannot overestimate how powerful a driver the Jisc Collections ebook initiative has been in providing a critical mass of materials freely available to students across the UK. There are now more ebooks on offer from publishers, and access to them has improved from the days of patchy arrangements focusing on fixed PCs with IP address authentication. Shibboleth access is now much more prevalent. There are creative partnerships in place in many colleges between library and lecturing staff which have promoted the practical uses and advantages of ebooks - increased accessibility, flexibility and functionality. Problems remain in the supply of ebooks, however; librarians find it hard at times to source good quality materials, and often the licences are complex and at times restrictive. There is work to be done by Jisc Collections on behalf 
of the FE sector nationally in securing a step-change in the supply of ebooks and the establishment of standards to ensure easy and effective access and usability.

\section{References}

Conyers, A. and Dalton, P. (2013) Analysis of E-books in FE Project Data. Birmingham: Birmingham City University.

Cox, J., Cox., L and Carden, M. (2010) Migrating to E in UK further education. London: Jisc Collections. 